\title{
NEKATERI ELEMENTI POVEZOVANJA SLOVENIJE S SOSEDNJIMI DRŽAVAMI
}

\author{
Mirko Pak*
}

Izvleček

UDK 911.3:33(497.12-04)

Članek prinaša analizo nekaterih elementov sodelovanja z Avstrijo, Hrvaško, Italijo, Madžarsko : trgovinska menjava, promet potnikov in turistični promet, vključuje pa še druge elemente soodvisnosti regionalnega razvoja in sodelovanja s sosednjimi državami.

Ključne besede: Meja, mejni prehodi, regionalni razvoj, trgovinska menjava, turistični promet, potniški promet, Slovenija

SOME LINKING ELEMENTS OF SLOVENE WITH NEIGHBOURING STATES

The article analyses some elements of cooperation with Austria, Hungary and Croatia: trade exchange, passenger and tourist traffic and other elements of regional development and cooperation with neighbouring states.

Key words: Border, border crossings, regional development, trade exchange, passenger and iourist traffic, Slovenia

\section{UVOD}

Bistveni značilnosti Slovenije sta njen geografski in geopolitični položaj, kar je spremljalo razvoj njenega teritorija tudi po drugi svetovni vojni kot federalne enote in končno kot samostojne države. O tem se je med ostalim veliko pisalo neposredno in posredno tudi $\mathrm{v}$ geografski literaturi in seveda o neposrednih posledicah tega. Med drugimi je zato tudi R. Pavič v svojih geostrateških analizah Jugoslavije in njenih posameznih območij vedno izpostavljal geostrateški položaj Slovenije (Pavič, 1973 ). Tudi nobena kompleksna družbenogeografska analiza bivše skupne države ni mogla mimo te položajne vloge Slovenije, kamor so kot skozi lijak prihajali iz "Evrope" vsi pomembnejši prometni, gospodarski, prebivalstveni, turistični in drugi tokovi in se pahljačasto razširjali naprej proti jugu in jugovzhodu. Tudi v bodoče ne bo drugače. $V$ vseh družbenogeografskih analizah Balkanskega polotoka je izpostavljena savsko - moravska prometna os in glavne prečne smeri iz Evrope proti Jadranu. Specifična na vsem območju JV Evrope je bila dolga desetletja tudi prehodnost slovenskih meja, bolj podobna zahodnoevropskim kot mejam v JV Evropi. Od tod in še iz številnih drugih razlogov narodnostne manjšine v Sloveniji in Slovenci onstran meja ter današnja nacionalna sestava prebivalstva, ki so jo skupaj z njenimi učinki

* Dr. prof., Oddelek za geografijo, Filozofska fakulteta, Univerza v Ljubljani, Aškerčeva 2, 61000 Ljubljana, SLO 
geografi več desetletij intenzivno proučevali in ki je vseskozi predstavljala most med Slovenijo in sosednjimi deželami. V tem je tudi iskati odgovor na to, da se je Slovenija že $v$ šestdesetih letih vključila $v$ regionalno povezovanje, ki se je razmahnilo $v$ sedemdesetih letih in se je v osemdesetih letih preusmerilo tudi v mednarodno sodelovanje in to prvenstveno na klasična področja sodelovanja: propustnost meje, izgradnja infrastrukture, sektorsko sodelovanje na raznih področjih, zlasti po osamosvojitvi pa je težišče močno poseglo na področje investicij, znanstveno raziskovalne dejavnosti, uporabo novih telekomunikacij in drugo (Bučar, 1993). Da je gradnja sodelovanja s sosednjimi državami (deželami) kompleksen, kompliciran in silno pomemben proces tako za državo, kot za vse segmente njenega funkcioniranja in razvoja, kakor tudi za obsežna obmejna območja, kažejo vsa dogajanja v zvezi s Hrvaško, s katero je bilo sodelovanje v drugačni institucionalni obliki v preteklosti na vseh področjih nadpovprečno. Pa tudi značaj tujih investicij v Slovenijo v obdobju 1985-91. Takrat je bilo iz Avstrije 269 ali 26,1\% vseh investicij, ki so predstavljale $26,2 \%$ vrednosti. Iz Italije je bilo 320 ali 31,0\% vseh investicij v vrednosti $15,6 \%$. Velikih razlik v namenu, strukturi in obsegu investicij iz obeh držav v Slovenijo najbrž ni treba posebej razlagati.

Ves razvoj Svet in še posebej Evropo vedno bolj povezuje in njene posamezne člene sili k vedno tesnejšemu sodelovanju. Regionalno povezovanje, nastajanje evropskih regij, skupnega evropskega urbanega sistema transnacionalnih dimenzij (Capellin, 1993), vključujejo tudi Slovenijo v vse te procese. Povečuje se splošna soodvisnost in ta se tudi v Sloveniji krepi, širi in še posebej obrača k sosednjim državam, ki so zaradi spremenjene družbeno - politične podobe Evrope vse bolj povezane. Zaradi specifičnega položaja, geografskega na obrobju Alp, ob izstopu transkontinentalnih prometnic, zaradi odprtosti proti morju in zaradi savske prometne smeri, je Slovenija v vseh pogledih ena tovrstno najbolj zanimivih evropskih regij. Posebnost Slovenije je tudi njena majhnost, zaradi česar ves teritorij neposredno čuti raznovrstne vplive sosednjih držav in obmejnosti. Predvidene boljše komunikacije bodo to še stopnjevale.

Prepletenost teh tokov vključuje vse sosede, še posebej pa Hrvaško, podobno kot je to za avstrijske Alpe E. Lichtenberger pokazala $\mathrm{z}$ gostoto, deležem in številom ter tendencami nadaljnjega širjenja vikendov v lasti Bavarcev (Lichtenberger, 1991).

Glede na to lahko govorimo o trostopenjskem vplivu meje na Slovenijo:

- v obmejnih območjih je ta lahko v regionalnem in gospodarskem, pa tudi v s socialnem razvoju, vsaj v nekaterih pogledih, celo pevladujoč,

- daleč v notranjost segajo vplivi zlasti do večjih središč v funkciji oskrbnih središč

- Avstrijci pretežno do Maribora, Italijani pa do Ljubljane, ali do turistično

- rekreacijsko privlačnih območij,

- zaradi majhnosti zajemajo določeni vplivi obmejnosti ves slovenski teritorij.

Pa si oglejmo povezovanje Slovenije s sosednjimi državami na primeru treh klasičnih področij meddržavnega sodelovanja, prometnih tokovih, trgovinski menjavi in turizmu. 


\section{MEJNI PROMET POTNIKOV V CESTNEM PROMETU}

Prekomejni prometni tokovi so najbolj razširjena in stabilna oblika meddržavnega sodelovanja, še posebej med sosednjimi državami. Tako je zlasti blagovni promet med deželami na obeh straneh "Železne zavese" nemoteno potekal v okviru potreb, še posebej, kar se surovin tiče. Prav lep primer za to je bila sicer močno izolirana Albanija, ki je izvažala rude $\mathrm{v}$ Jugoslavijo in drugam in $\mathrm{v}$ katero je na primer iz Bolgarije prihajal tranzitni promet $v$ luko Drač.

Slovenija ima specifično in zelo ugodno prometno lego nasploh in tudi v odnosu do sosednjih držav. Razen neposrednega prometa v Slovenijo in iz nje, je Slovenija prometna vez med razvitimi evropskimi makroregijami (alpsko - panonski, gorsko - Dinarski in primorski prostor), pa tudi vez sosednjih s številnimi drugimi državami. Najnovejše politične spremembe so te prometne smeri valorizirale in ni slučaj, da promet $v$ Sloveniji s sosednjimi državami kljub nepretrganim vezem proti jugu ni utrpel večje škode. V odnosu do Hrvaške in Madžarske pa je celo pridobil. Hrvaški predstavlja Slovenija velik del okna v svet in edino racionalnejšo povezavo z zahodnoevropskimi državami, Madžarski pa je liberalizacija mejnega prehajanja in usmeritev prometa preko Slovenije hkrati tudi pomenila večjo usmeritev na Slovenijo, tudi kar se tranzita preko Kopra tiče. Če prištejemo še Avstrijo, se ni čuditi, da tovorni promet v luki Koper raste.

Stabilizacija političnega stanja na Balkanu bo nedvomno močno dvignila prometno vrednost in tudi obremenjenost Slovenije, ki bo še stopnjevana $\mathrm{z}$ obnovo $v$ vojni prizadetih območij s prodorom kapitala, blaga, opreme in drugega $v$ ostale dežele bivše Jugoslavije ter $\mathrm{z}$ vsemi drugimi oblikami "osvajanja novih dežel", ki so razvitim evropskim državam na dosegu roke. V tem ima Slovenija nedvomno velike možnosti na vseh gospodarskih področjih.

Na splošno je promet s sosednjimi državami v predvojnih letih, vključno s 1988 . letom naraščal, kasneje pa večinoma stagniral ali celo rahlo nazadoval. Za obdobje od predvojnih let do danes je začilno močno nazadovanje železniškega in letalskega prometa, stagnacija v pomorskem in rast cestnega prometa, kar v glavnem velja tako za potniški, kot za blagovni promet. Na splošno pa je že leta 1992 promet $v$ glavnem naraščal $\mathrm{z}$ izjemo prometa iz Italije in leta 1993 je bilo naraščanje še hitrejše. Podatki za prvih deset mesecev v letu 1993 kažejo tekom leta močan porast tako uvoza kot izvoza in tranzita iz sosednjih držav z viškom v mesecu juliju.

Indeks potniškega prometa s sosednjimi državami v obdobjih I.-VII.1993 in za enako obdobje v letu 1992 je znašal 128, z Italijo 126, Avstrijo 105, Madžarsko 348 in Hrvaško 171. Najbolj se je povečal potniški promet z Madžarsko in Hrvaško. Podatki za prvih deset mesecev v 1993. letu pa kažejo, da bo obseg potniškega prometa $\mathrm{z} v$ vsemi štirimi sosednjimi državami do konca 1993. leta presegel vrednosti iz 1992. leta. 
Nekateri elementi povezovanja...

Slika 1: Turistični promet s sosednjimi državami

Tourist visits from neighbouring countries

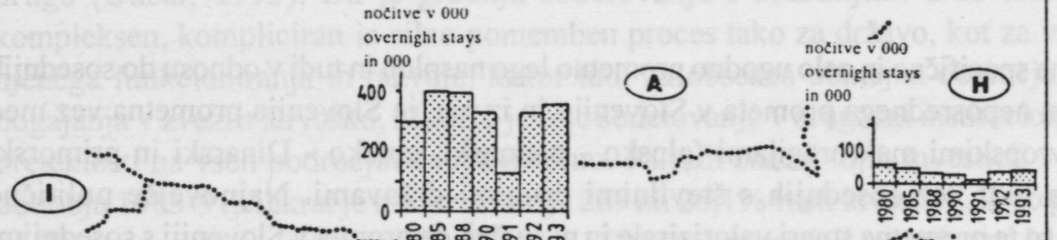

nocitve $v 000$
overnight stays

2004

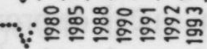

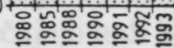

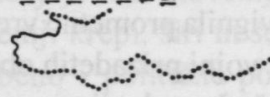

To ad nocitev tujin gostov

\% overnight stays from fercign tourists
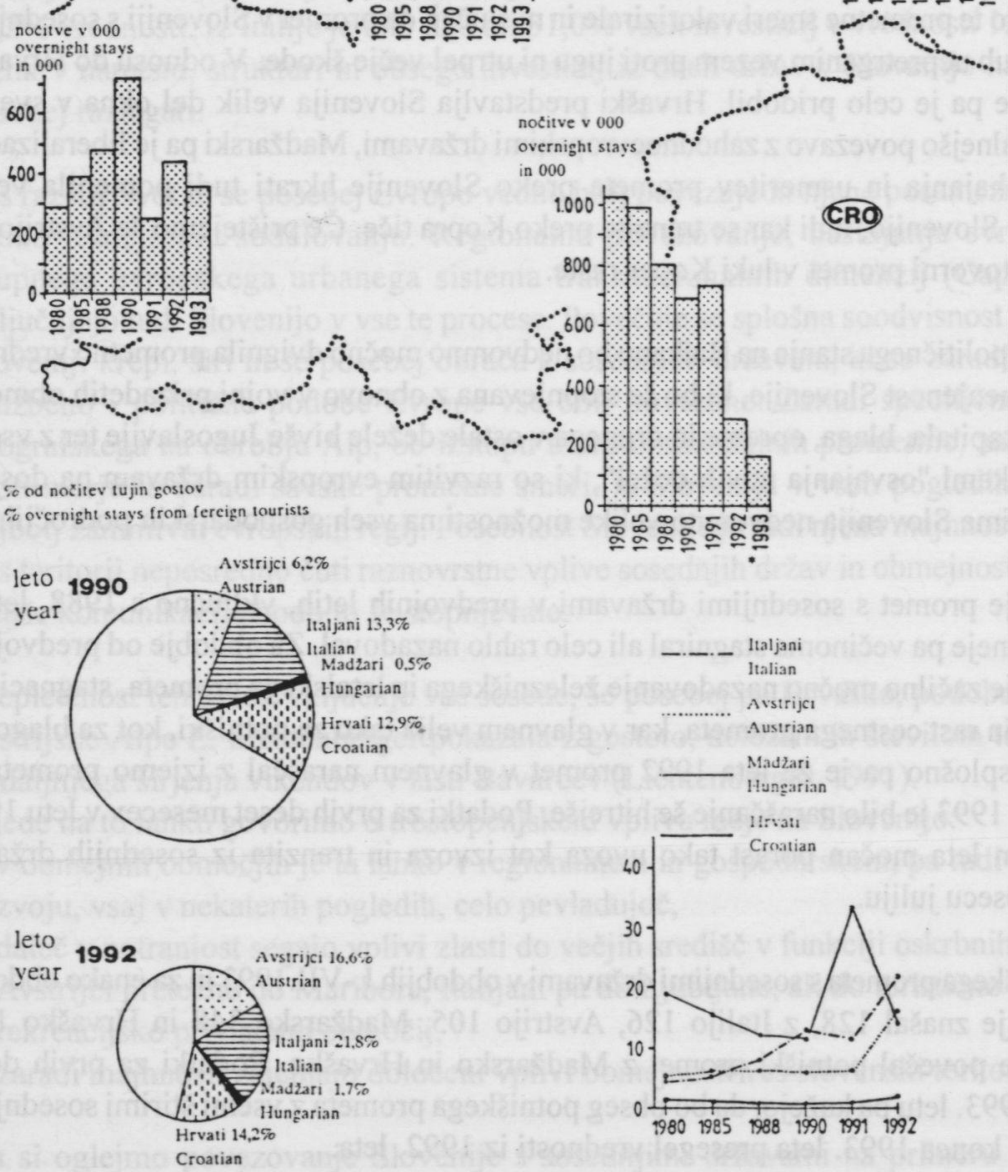

- 1. X.1993 
Tab. 1: Delež sosednjih držav v potniškem prekomejnem prometu The Share of Neighbouring Countries in the Transborder Traffic

\begin{tabular}{lrrrr}
\hline & 1980 & 1988 & 1992 & $\begin{array}{r}1993 * \\
\text { (I.-X.) }\end{array}$ \\
\hline Avstrija & $10,0 \%$ & $11,2 \%$ & $10,3 \%$ & $8,9 \%$ \\
Hrvaška & - & - & $19,4 \%$ & $21,2 \%$ \\
Italija & $25,4 \%$ & $29,8 \%$ & $22,9 \%$ & $21,9 \%$ \\
Madžarska & $0,4 \%$ & $0,3 \%$ & $0,9 \%$ & $1,6 \%$ \\
Skupaj & $35,8 \%$ & $41,3 \%$ & $63,5 \%$ & $53,6 \%$
\end{tabular}

* Vsi podatki za leto 1993 so le za prvih deset mesecev.

Predvsem je v potniškem prometu močno porastel delež Madžarske, kar velja še bolj za njen tovorni promet in delež Hrvaške. V primerjavi s celotnim letom 1992 so samo v desetih mesecih 1993. leta dosegli naslednji obseg prometa: Avstrija 88,5\%, Hrvaška 112,5\%, Italija $100 \%$ in Madžarska 183\%. Celotni potniški promet s sosednjimi državami pa je leta 1993 znašal kar 78\% v letu 1992 doseženega prometa.

\section{TRGOVINA S SOSEDNJIMI DRŽAVAMI}

Obseg trgovinske menjave s sosednjimi državami kaže večja nihanja kot promet. Predvsem je trgovinska menjava naraščala, vendar iz politično - gospodarskih razlogov hitreje uvoz kot izvoz iz Slovenije. Po osamosvojitvi pa je ta razlika še občutnejša, kar velja tudi za leto 1993 (Karta 2). Močno so zlasti prizadeti trgovinski tokovi s Hrvaško, kjer gre za splošno zmanjšanje menjave. V primeru Italije in Avstrije gre za izrazito zmanjšanje izvoza, pa tudi z Madžarsko blagovni tokovi za Slovenijo niso bili najbolj ugodni.

Delež treh sosednjih držav, brez Hrvaške, se je v celotni trgovinski menjavi Slovenije zmanjšal s $26,0 \%$ leta 1988 na $19,5 \%$ leta 1992 in uvoz s $24,7 \%$ na $24,2 \%$. Iz pozitivne se je, zlasti na račun Italije, trgovinska menjava spremenila v negativno. $V$ tem se kažejo vse gospodarske težave ob prestrukturiranju gospodarstva. Trpi seveda tudi že utečena živahna trgovinska menjava med obmejnimi regijami. Vsekakor pa se odnos med gospodarsko bolje in slabše razvitimi državami kaže $v$ različnih uvozno - izvoznih odnosih s sosednjimi državami, ki bi morali biti intenzivnejši.

\section{TURISTIČNI PROMET IZ SOSEDNJIH DRŽAV}

Slovenija kot turistična dežela je močno privlačna tudi za goste iz sosednjih držav. Zaradi raznolikih sosedov pa so bile $v$ zadnjih desetletjih velike razlike $v$ turističnih obiskih iz 
Slika 2: Trgovina s sosednjimi državami

Commerce and Trade with neighbouring countries

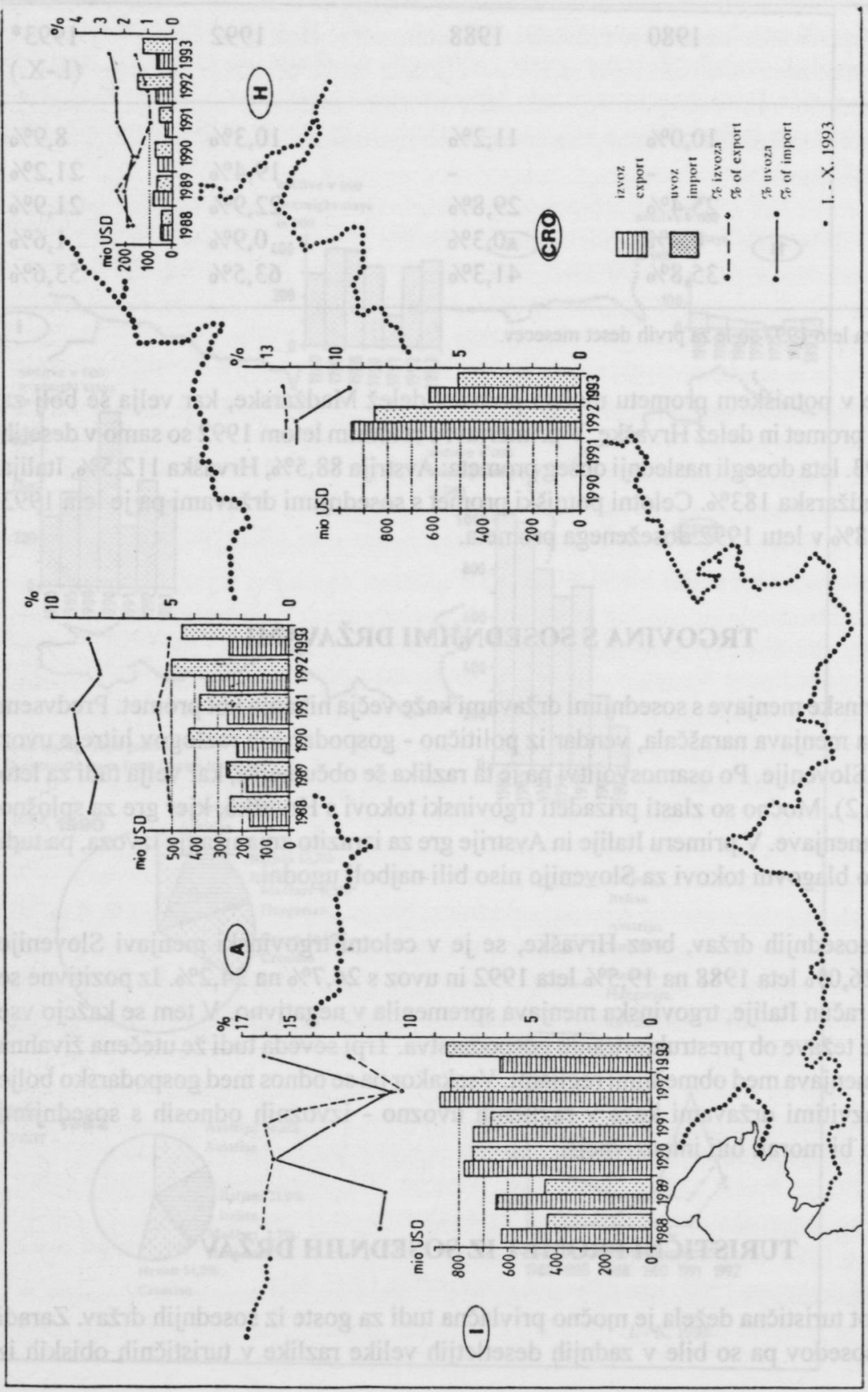


Nekateri elementi povezovanja...

vseh štirih držav. Prvotnemu naraščanju je sledila že pred vojno stagnacija ali celo nazadovanje, pri čemer so bili vzroki notranji in zunanji. Med notranjimi je bil na prvem mestu gotovo dvig cen turističnih uslug in drugih storitev, ki je najbolj prizadel goste iz Madžarske in Hrvaške, katerim je tudi pojemala kupna moč (Karta 3). Na to se je odzval tudi obisk turistov iz Avstrije. Le iz gosto poseljenega italijanskega sosedstva se je, ob izboljšanju naše turistične infrastrukture, zaradi tradicionalne usmeritve, bližine in ostalega, promet vse do vojne večal. Skupno število turističnih nočitev tujih gostov je že leta 1990 nazadovalo.

Posebno leto 1991 beleži zmanjšanje števila nočitev tujih turistov z izjemo Hrvaške, ki so jo politične in s tem povezane gospodarske spremembe prizadele še posebej v letu 1992, ko je število njihovih nočitev najbolj nazadovalo. $V$ teh dveh leti se je število gostov iz sosednjih držav zmanjšalo na eno tretjino.

Že leta 1992 je število nočitev gostov iz Italije, Avstrije in Madžarske ponovno poraslo. Njihov delež v prenočitvah tujih gostov pa se je skoraj podvojil in od $28,2 \%$ leta 1988 narasel na $54,3 \%$ leta 1992 , po državah pa od tri do štirikrat.

Tab. 2: Delež sosednjih držav v nočitvah tujih turistov

The Share of Tourists from Neighbouring Countries

\begin{tabular}{lrrrrr}
\hline & 1980 & 1990 & 1991 & 1992 & $1993 *$ \\
\hline Avstrija & $5,5 \%$ & $6,2 \%$ & $6,3 \%$ & $16,6 \%$ & $20,1 \%$ \\
Hrvaška & $19,2 \%$ & $12,9 \%$ & $33,3 \%$ & $14,2 \%$ & $9,2 \%$ \\
Italija & $5,4 \%$ & $13,3 \%$ & $11,5 \%$ & $21,8 \%$ & $20,0 \%$ \\
Madžarska & $1,2 \%$ & $0,5 \%$ & $0,5 \%$ & $1,7 \%$ & $3,2 \%$ \\
Skupaj & $31,3 \%$ & $32,9 \%$ & $51,6 \%$ & $54,3 \%$ & $52,2 \%$ \\
\hline
\end{tabular}

Ob ostalih dejavnikih mednarodnega sodelovanja je turistični promet nedvomno eden najpomembnejših, še posebej za številna turistična in obmejna območja. Razmah gradnje turistične infrastrukture in tudi tujih naložb $v$ to gospodarsko panogo kažejo na povečano zanimanje tujine za turistično ponudbo Slovenije. To velja tudi za turistični promet iz sosednjih držav, še posebej na osnovi vikend - turizma, ki bo v bodočnosti zagotovo močneje udeležen, kot doslej. 
Slika 3: Mejni promet potnikov v cestnem prometu

Crossings of borders by passangers in vehicles

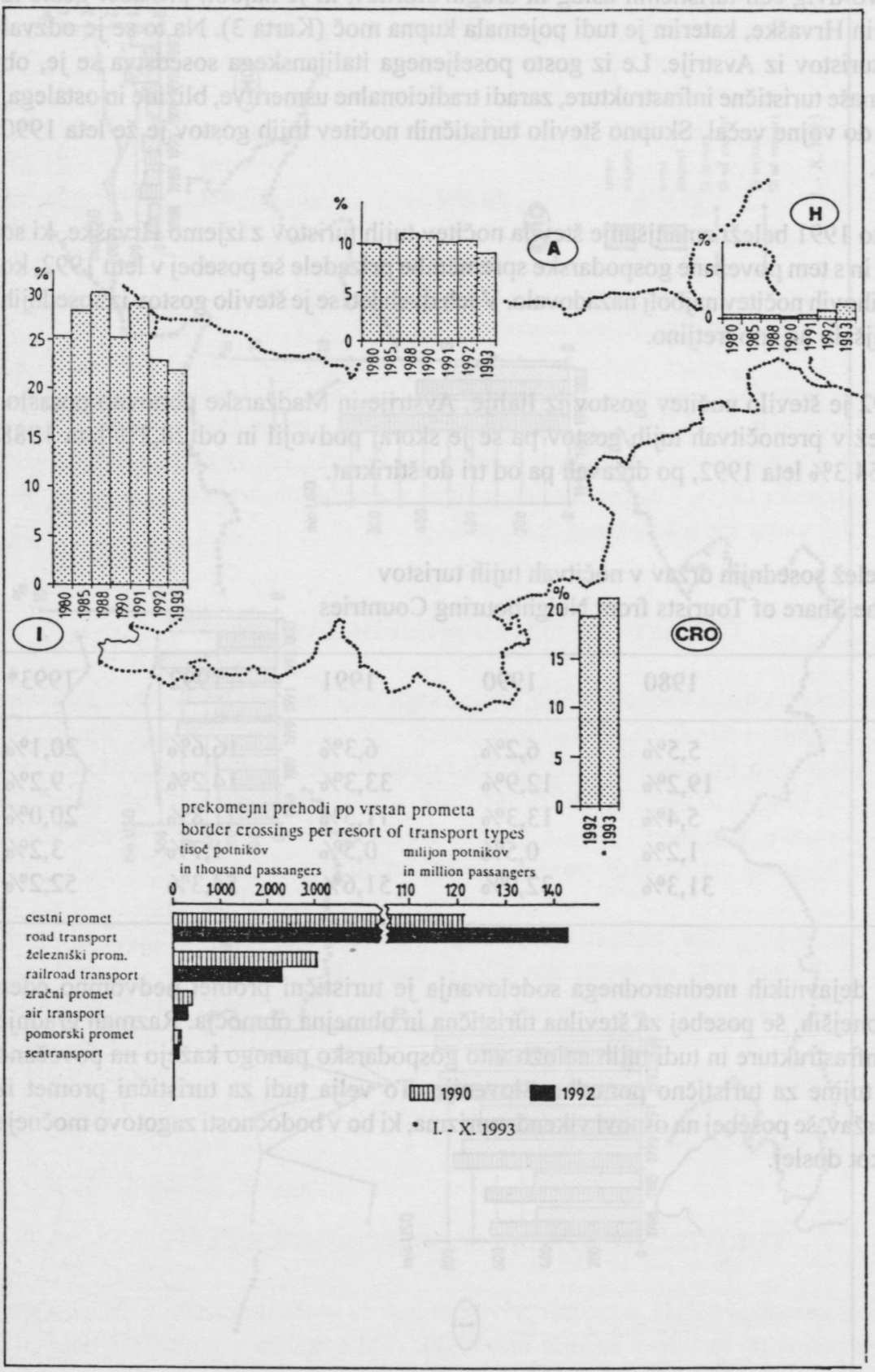


Nekateri elementi povezovanja...

\section{ZAKLJUČEK}

Sodelovanje Slovenije $s$ sosednjimi državami se kvalitativno in kvantitativno širi in relativni pomen tega narašča. Končno predstavlja Slovenija vsem sosedom tudi vrata v neko od njihovih življenjsko pomembnih smeri (Italija na vzhod, Madžarska in Avstrija na morje, Hrvaška v Evropo, itd.), kar se najočitneje manifestira v prometnem interesu in spremljajoči infrastrukturni opremljenosti. Vse to bo prineslo očitne razvojne spremembe v urbanizaciji, gospodarskem pogledu, s čimer bo povezano povečano število delovnih mest, prestrukturiranje prebivalstva in še vse druge gospodarske in socialne spremembe ter seveda degradacija okolja.

Ob tem se pojavlja vrsta vprašanj regionalnega razvoja. Ali bo ta razvoj prinesel pretežno nadaljnjo razvojno koncentracijo $\mathrm{v}$ obstoječih razvojnih polih in razvojnih koridorjih, torej linearno, ali bodo učinki tega enakomerneje prisotni na širšem državnem teritoriju, torej ploskovno? Kako se bodo v to vključila vsa obmejna območja, med katerimi so številna obrobna in odročna? Ali se bodo ta le enostransko razvijala za zadovoljevanje določenih potreb prebivalstva sosednjih držav v smislu trgovine, gostinstva in še kakšne od storitvenih dejavnosti, kar je bilo ob naši zahodni meji že doslej prisotno? Ali se bo dejavnostna in druga sestava prebivalstva $v$ teh območjih izboljšala, se bodo življenjski pogoji približali razvitim območjem? Ali bodo in v kakšni smeri $v$ območjih in še posebej $v$ atraktivnih območjih, med katere sodijo tudi naša urbana središča in še posebej Ljubljana, zemlja in druge nepremičnine prehajale $\mathrm{v}$ tuje roke? Kakšni bodo kulturni in drugi vplivi sosednjih držav pri nas (primer mariborskega območja, kjer se povsod iz radioaparatov sliši nemščina in nemška zabavna glasba)? Kaj bodo Sloveniji prinesle investicije iz sosedstva v proizvodne panoge? Kaj nam bodo prinesle nove prometnice? In še cela vrsta je vprašanj, na katera bi med drugim morali odgovoriti tudi geografi na osnovi dosedanjh spoznanj, ki jih je v literaturi dovolj in smo na en primer že opozorili?

Vsa dosedanja spoznanja kažejo na povečano zanimanje za sodelovanje med sosednjimi državami in regijami. V to silijo tudi najnovejši razvojni tokovi, pa tudi razvojna politika EU. Povezovanje sosednjih dežel in skupno zastopanje jim bo omogočilo tudi ustreznejšo zastopanost $v$ delitvi celotne evropske razvojne pogače. Slovenija pa mora računati tudi $z$ močno povečanimi vsestranskimi kontakti s Hrvaško, še posebej po ureditvi političnih razmer na Balkanu, ko bodo na Slovenijo zaradi njene geografske lege, kljub političnim spremembam, še vedno odpadle nekatere funkcije gospodarske, prometne in druge prehodnosti in povezovanja različnih makroregionalnih območij Evrope. 
Nekateri elementi povezovanja...

\section{LITERATURA}

Bučar, B., 1993, Čezmejno in mednarodno sodelovanje evropskih subnacionalnih regij. Bufon, M., 1989, Regionalni razvoj obmejnih regih regij. Magistrsko delo. Ljubljana. Cappellin, R., 1993, Regionaleconomic development. Regionalism and interregional cooperation : the role of regions in a policy for European cohesion. Referat na International cometition and cooperation in an englared Europe. Joensuu.

Lichtenberger, E., 1991, Das Haus Europa und die Alpen. Socialgeographische Szenarien. Die Alpen im Europa der neunziger Jahre. Bern, str. 15-49.

Pak, M., 1978, Geographische Elemente der Funktion Versorgung im Grenzraum entlang der Jugoslawisch-italienische Grenze. Geographica Slovenica 8. Ljubljana, s. 21-27.

Pavić, R., 1973, Osnove opče i regionalne političke geografije, geopolitike, geostrategije. Zagreb.

Statistični letopis Republike Slovenije 1993. Ljubljana.

\section{SOME LINKING ELEMENTS OF SLOVENE WITH NEIGHBOURING STATES}

\section{Summary}

Already in the former Yugoslavia, the relation of Slovenia towards the neighbouring countries, i.e. Austria, Italy, and Hungary, was specific. The borders with Austria and Italy were by far the most open when compared to other Yugoslav borders. With both these countries, and with Hungary as well, Slovenia intensively cooperated which resulted in the formation of typical European dynamic regions along the borders, with the Italian border in particular. Slovenia used to be kind of a bridge between West, Central and also North Europe and the rest of Yugoslav territory and the Balkan penninsula, and farther on towards the Middle East. The great majority of goods, financial and passenger flows to the above mentioned areas ran through Slovenia which is, due to its geographic and geopolitical position, a country of an explicity transit transport character.

The independence, declared on June 25, 1991, when Slovenia became a sovereign state, caused, with the democratization process and introduction of market economy, that Slovenia further increased its cooperation with the neighbouring countries, while the new state border with Croatia has brought a number of unsolved problems related to the questions of border, property, and other matters.

The most intense and frequent elements of direct cooperation and connection with the neighbouring countriesare the ones which are related to the location ofthe areas by the border. On the $235 \mathrm{~km}$ long Slovene-Italian border, there are 68 border crossings, 14 of which are international - railway and road crossings, the rest are local crossings, for local residents and owners of the land on both sides of the border. On the $324 \mathrm{~km}$ of Slovene- 
Austrian border, there are 47 border crossings, 16 of which are international. On the 102 $\mathrm{km}$ long Slovene-Hungarian border, there are 4 border crossings, 2 of which are international. On the $546 \mathrm{~km}$ long Slovene-Croatian border, there are 34 border crossings, 27 of which are international. The occurence of border crossings, of bigger ones in particular, strongly depends on the relief features, as well as the density of settling and the degree of contacts between Slovenia and the neighbouring countries and between the border areas on both sides.

The flows of employment across the border have only increased since the economy came under recession. In Austria, the greatest number among the employed that come from former Yugoslavia are the Slovenes. Slovenia, havin been the most developed republic in former Yugoslavia employed a lot of workers from othern federal republics. The result in the increased number of non-Slovene population, from $6 \%$ in 1971 to $12.2 \%$ in 1991 . The percentage of Croats in Slovenia increased from $2.5 \%$ to $2.8 \%$ only.

An old process going on in the regions along the borders is across-the border supply flows, which is based on price differences and other things. While, on the Italian and Austrian sides, numerous smaller or bigger centers have developed on this basis, such as Trieste (Trst), Gorizia (Gorica), Udine (Videm), Tarvisio (Trbi'), Villach (Beljak), Klagenfurt (Celovec), Graz (Gradec), Leibnitz (Lipnica), Radkesburg (Radgona), Bleiburg (Pliberk), etc., this infrastructure is not so evident on the Slovene side, in spite of mass supply flow from Italy to Slovenia. Since it is often connected with tourist visits, in western Slovenia in particular, it offers to wider areas along the borders an additional economic contribution.

A special type of communication between neighbouring countries is going on among national minorities on both sides of a border.

Slovenia used to have the role of a gate leading to Yugoslavia; the transport function did not decline so much when the northwest-southeast direction was closed, because the importance on the west-east direction increased, i.e. from Spain, south France, and especially Italy, towards Hungary and further on to the east. New border crossings on the SloveneHungarian border should also be mentioned in this connection, as well as the Karavanke tunnel, highway connection with the Phyrn highway, and transport directions towards Croatia. Thus, along with the ever more important Ljubljana transport node, the eastern one, i.e. Vienna-Zagreb- Budapest is also gaining ever greater importance. 